\title{
PELATIHAN PENYUSUNAN LAPORAN KEUANGAN BERBASIS SAK SYARIAH 109 KHUSUSNYA PENGELOLAAN DANA INFAK/SEDEKAH PADA SMAN 1 PAKUSARI JEMBER
}

\section{THE CONSTRUCTION TRAINING OF FINANCIAL STATEMENTS BASED ON SAK SHARIA 109 SPECIAL MANAGEMENT OF INFAK/ALMS FUND IN SMAN 1 PAKUSARI JEMBER}

\author{
Rendy Mirwan Aspirandi \\ Fakultas Ekonomi Universitas Muhamamdiyah Jember \\ E-mail: rendymirwanaspirandi@unmuhjember.ac.id
}

\begin{abstract}
ABSTRAK
Salah satu yang melatarbelakangi pentingnya dilakukan pelatihan pelaporan keuangan berdasarkan Standar Akuntansi Keuangan (SAK) Syariah adalah kurangnya pengetahuan para pengelola masjid mengenai pencatatan dan pelaporan keuangan dana masjid berdasarkan Standar Akuntansi Keuangan (SAK) Syariah. Metode pelaksanaan pengabdian masyarakat ini diselenggarakan dengan metode ceramah, diskusi, dan praktik. Metode tersebut digunakan untuk menyampaikan materi tentang penyusunan laporan keuangan berbasis SAK Syariah 109 khususnya pengelolaan dana infak/sedekah pada SMAN 1 Pakusari Jember. Kegiatan pelatihan untuk penyusunan laporan keuangan berbasis SAK Syariah 109 pada Sekolah Menengah Atas Negeri (SMAN) 1 Pakusari Kabupaten Jember. Faktor pendukung terlaksananya kegiatan pengabdian masyarakat ini antara lain: (1) adanya motivasi dari pihak SMAN 1 Pakusari Jember untuk mengetahui lebih dalam mengenai SAK Syariah 109, (2) tingginya antusias dari pihak siswa/siswi SMAN 1 Pakusari Jember untuk mengikuti seluruh rangkaian kegiatan pelatihan penyusunan laporan keuangan berbasis SAK Syariah 109 yang terlihat pada sesi tanya jawab dan diskusi siswa/siswi SMAN 1 Pakusari Jember, dan (3) dukungan dari pihak Lembaga Penelitian dan Pengabdian Masyarakat dan Fakultas Ekonomi Universitas Muhammadiyah Jember.
\end{abstract}

Kata Kunci : $\quad$ SAK Syariah 109, SMAN 1 Pakusari Jember, dan Infak/Sedekah

\begin{abstract}
One of the reasons behind the importance of financial reporting training based on Sharia Financial Accounting Standard (SAK) is the lack of knowledge of mosque managers regarding the recording and reporting of mosque finance funds based on Sharia Financial Accounting Standards (SAK). This method of social dedication is organized by lecture, discussion, and practice. The method is used to convey the material about the preparation of financial statements based on SAK Sharia 109 especially the management of infaq/alms funds at SMAN 1 Pakusari Jember. Training activities for the preparation of financial statements based on SAK Sharia 109 at Senior High School (SMAN) 1 Pakusari Jember District. Factors supporting the implementation of social dedication activities include: (1) the motivation of SMAN 1 Pakusari Jember to know more about SAK Sharia 109, (2) the high enthusiasm of the students of SMAN 1 Pakusari Jember to follow the whole series of training activities of the preparation of financial statements based on SAK Sharia 109 which looks at the question and answer session and discussion of students of SMAN 1 Pakusari Jember, and (3) support from the Institute of Research and Social Dedication and Faculty of Economics, Muhammadiyah University of Jember.

Keyword : SAK Sharia 109, SMAN 1 Pakusari Jember, and Infak/Alms.
\end{abstract}




\section{PENDAHULUAN}

Perkembangan jumlah masjid di Indonesia sangat pesat. Data terakhir yang diterbitkan oleh salah satu media cetak bahwa jumlah masjid di Indonesia lebih dari 800.000 (nasional.kompas.com). Setiap masjid pasti melakukan pengelolaan didalamnya. Baik pengelolaan sumber daya manusia maupun sumber daya keuangan. Sumber daya manusia dapat berasal dari pemuka-pemuka agama (ustadz) yang mengisi kegiatankegiatan dalam masjid tersebut. Pengelolaan keuangan dalam masjid sangat penting dilakukan, supaya aliran kas masuk dan keluar dari masjid yang bersangkutan menjadi transparan dan terkelola dengan baik. Sesuai dengan ajaran agama islam bahwa "Hai orang-orang yang beriman, apabila kamu bermu'amalah tidak secara tunai untuk waktu yang ditentukan, hendaklah kamu menuliskannya. Dan hendaklah seorang penulis di antara kamu menuliskannya dengan benar. Dan janganlah penulis enggan menuliskannya sebagaimana Allah mengajarkannya, meka hendaklah ia menulis, dan hendaklah orang yang berhutang itu mengimlakkan (apa yang akan ditulis itu), dan hendaklah ia bertakwa kepada Allah Tuhannya, dan janganlah ia mengurangi sedikitpun daripada hutangnya..." (Q.S. Al Baqarah ayat 282).

Masyarakat menuntut pengelolaan keuangan masjid secara transparan. Satusatunya jalan pengelola masjid untuk melakukan transparansi pengelolaan keuangan masjid adalah akuntansi. "Akuntansi dalam entitas tempat ibada (masjid) dijadikan tolok ukur kinerja para pengurus masjid selaku Takmir dan Bendahara masjid (Hanafi, 2015). "Sebagai entitas pelapor akuntansi yang menggunakan dana masyarakat sebagai sumber keuangannya dalam bentuk sumbangan, sedekah atau bentuk bantuan social lainnya yang berasal dari masyarakat (publik), Masjid menjadi bagian dari entitas publik yang semua aktivitasnya harus dipertanggungjawabkan kepada publik." (Latif, 2014).

Perkembangan kemajuan mengenai pelaporan akuntansi bagi masjid ditandai dengan terbitnya SAK Syariah. "Standar Akuntansi Syariah (SAS) adalah Pernyataan Standar Akuntansi Keuangan (PSAK) Syariah yang ditujukan untuk entitas yang melakukan transaksi syariah baik entitas lembaga syariah maupun lembaga non syariah" (iaiglobal.or.id). Standar Akuntansi Keuangan Syariah ini lebih relevan digunakan dalam pengelolaan keuangan masjid sebagai bentuk akuntabilitas publik. SAK syariah 109 lebih tepatnya yang membahas menganai pengeloaan dana zakat dan infak/sedekah. 
Perkembangan kemajuan akuntansi dalam mengatur mengenai transparansi pelaporan keuangan masjid masih tidak diimbangi dengan perkembangan penerapannya dalam pengelolaan keuangan masjid di Indonesia. "Banyak masyarakat yang antipati terhadap masjid, dikarenakan pengurus masjid tidak transparan dalan memberikan laporan keuangan dan pengelolaan masjid yang tidak baik menyebabkan jamaah masjid banyak yang keluar"'(Andarsari, 2016). Pengetahuan mengenai pengelolaan dana masjid juga perlu ditanamkan kepada khalayak umu termasuk taraf Sekolah Mengeah Atas (SMA), supaya di masa depan dapat mengelola dana masjid di kehidupan masyarakat.

Sekolah Mengah Atas Negeri (SMAN) 1 Pakusari merupakan SMA negeri terbesar di sekitar pakusari. SMAN 1 Pakusari merupakan SMA negeri yang bertempat di Jalan PB. Sudirman 120 Pakusari Kabupaten Jember. SMAN 1 Pakusari juga pasti memiliki masjid yangh menyebabkan pengelola harus bekerja ekstra dalam pengelolaan keuangan masjid dalam hal kas keluar dan masuk serta pengelolan mengenai biaya operasional masjid. Tidak sampai disitu, pengelola masjid SMAN 1 Pakusari juga harus mampu mempertanggungjawabkan segala aliran dana keuangan masjid.

Salah satu yang melatarbelakangi pentingnya dilakukan pelatihan pelaporan keuangan berdasarkan Standar Akuntansi Keuangan (SAK) Syariah adalah kurangnya pengetahuan para pengelola masjid mengenai pencatatan dan pelaporan keuangan dana masjid berdasarkan Standar Akuntansi Keuangan (SAK) Syariah. Banyaknya dana yang didapatkan oleh masjid khususnya dana yang berasal dari infak/sedekah harus dilakukan pencatatan dan dilaporkan secara transparan termasuk penyaluran dananya yang berdasarkan Standar akuntansi Keuangan (SAK) Syariah. Program pengabdian masyarakat seperti yang dilakukan pada SMAN 1 Pakusari ini merupakan wujud dari dukungan kelembagaan dari Universitas Muhammadiyah Jember untuk memberikan pelatihan penyusunan laporan keuangan khususnya dana infak/sedekah berbasis SAKSyariah 109.

Masjid merupakan tempat ibadah umat islam. "Kata masjid berasal dari bahasa arab yaitu sajada-yasjudu-sujuudan yang memiliki arti sujud menundukkan kepala sampai ke tanah. Dari kata sajada kemudian terbentuk kata masjid (jamak: masaajid) yang artinya tempat sujud" (Setiawan, 2010:10). Masjid memiliki berbagai fungsi dalam penggunaannya. "Fungsi utama masjid adalah tempat sujud kepada Allah SWT., 
tempat shalat, dan tempat beribadah kepada Allah SWT." (Ayub, Muhsin, dan

Mardjoned, 1996:7). Selain itu masih terdapat banyak fungsi masjid, antaralain.

1. Masjid sebagai tempat bermusyawarah kaum muslimin guna memecahkan permasalahan yang timbul dalam masyarakat,

2. Masjid sebagai tempat berkonsultasi, mengajukan solusi dalam setiap permasalahan, meminta pertolongan dan bantuan,

3. Masjid sebagai tempat membina keutuhanikatan jamaah dan kegotong-royongan di dalam mewujudkan kesejahteraan bersama,

4. Masjid sebagai tempat meningkatkan kecerdasan dan ilmu pengetahuan uslimin, dan

5. Masjid sebagai tempat mengumpulkan dana, menyimpan, dan membagikan kepada kaum-kaum yang membutuhkan.

Pengelolaan masjid pada saat ini memerlukan ilmu yang kuat engenai pengelolaan (manajemen). Para pengurus masjid harus siap dalam menghadapi segala perkembangan zaman dan tuntutan perkembangan dari berbagai pihak. "Administrasi merupakan aktivitas yang dilakukan guna menciptakan sistem yang selaras dan terkoordinasi untuk mencapai suatu tujuan yang seimbang sesuai dengan perencanaan" (Ayub, Muhsin, dan Mardjoned, 1996:30).

Pengurus masjid disebut juga dengan Takmir Masjid. Takmir Masjid adalah sekumpulan orang yang mempunyai kwajiban memakmurkan masjid. Takmir masjid sebenarnya telah bermakna kepengurusan masjid, namun tidak salah bila kita menyebut "Pengurus Takmir Masjid". Firman Allah : "Sesungguhnya orang-orang yang memakmurkan masjid Allah ialahorang-orang yang beriman kepada Allah dan hari akhir, menegakkan shalat, mengeluarkan zakat dan tidak takut kecuali hanya kepada Allah. Karena itu semoga mereka termasuk orang-orang yang mendapat hidayah“. (QS. AtTaubah: 18).

Sebuah masjid harus memiliki beberapa perangkat yang berperan dalam menangani berbagai kegiatan masjid. Diantara perangkat tersebut adalah:

1. Imam dan khatib masjid

2. Pengajar yang biasa memberikan kuliah dan pelajaran di masjid di samping sebagai pengawas jalannya pengajaran dan pendidikan di masjid.

3. Pengelola perpustakaan masjid 
4. Pengelola kegiatan sosial masjid.

5. Pengurus ramaja masjid.

6. Muadzzin dan pengajar hafalan Al Quran

7. Pengawas bidang bantuan kecelakaan.

8. Pekerja yang mangurusi kebersihan dan taman masjid.

Akuntabilitas masjid sangat diperlukan ketika masjid sudah berkembang semakin besar dan memiliki banyak donator. "Masjid merupakan organisasi non proft dimana pengurus masjid berfungsi sebagai agent yang berkewajiban mengatur dan melaporkan penggunaan dana yang diberikan oleh principal." (Siskawati, Ferdawati, dan Surya, 2016).

Islam memiliki tiga konsep dasar tentang hidup, yakni tauhid (keesaan Allah), khalifah dan keadilan ( 'adalah). Dari ketiga konsep ini kita dapat menurunkan nilai-nilai yang dikandung akuntabilitas Islam. Tauhid menjadi pondasi akuntabilitas Islam. Dengan tauhid manusia bersaksi bahwa tiada Tuhan yang patut disembah selain Allah. Dengan kesaksian ini, maka manajemen harus patuh pada aturan Allah dalam mengelola organisasi. Kesaksian ini juga mengisyaratkan kepada manajemen untuk menafikan segala keinginan stakeholder lain jika bertentangan dengan aturan Allah SWT. Konsep keadilan memandang bahwa dalam segala aktivitas hidupnya, manusia senantiasa harus menegakkan keadilan. Manusia dalam menjalankan tugas sebagai hamba Allah harus menegakkan keadilan. Manusia dalam mengelola bumi dan menyebar manfaat harus berlaku adil. Menegakkan keadilan juga berarti manusia ketika menerima amanah atau tugas harus memberikan pertanggungjawaban. Konsep khalifah dan keadilan kemudian menjadi pilar akuntabilitas Islam. Kombinasinya dengan konsep tauhid sebagai pondasi membuat bangunan akuntabilitas Islam tegak. Tanpa pemahaman terhadap konsep khalifah maka manusia hanya akan menjadi ahli ibadah dan tidak mengelola bumi untuk kemajuan manusia. Tanpa konsep keadilan, manusia akan berbuat seenaknya. Manusia yang kuat akan menindas yang lemah. Kezaliman akan terjadi dimanamana. Tanpa konsep khalifah dan keadilan maka tidak akan ada kesadaran bahwa suatu saat nanti manusia akan memberi pertanggungjawan. Tidak akan ada pemahaman bahwa akuntabilitas manusia akan dipertanyakan.

Pada SAK Syariah 109 khususnya pencatatan dan pelaporan dana infak/sedekah telah dijelaskan mengenai pengertian-pengertian dari akun-akun yang akan digunakan 
dalam proses pencatatan dan pelaporan. Pengakuan awal infak/sedekah, Infak/sedekah yang diterima diakui sebagai dana infak/sedekah terikat atau tidak terikat sesuai dengan tujuan pemberi infak/sedekah sebesar: (a) jumlah yang diterima, jika dalam bentuk kas; (b) nilai wajar, jika dalam bentuk nonkas. Penentuan nilai wajar aset nonkas yang diterima menggunakan harga pasar untuk aset nonkas tersebut. Jika harga pasar tidak tersedia, maka dapat menggunakan metode penentuan nilai wajar lainnya sesuai yang diatur dalam PSAK yang relevan. Infak/sedekah yang diterima diakui sebagai dana amil untuk bagian amil dan dana infak/sedekah untuk bagian penerima infak/sedekah. Penentuan jumlah atau persentase bagian untuk para penerima infak/sedekah ditentukan oleh amil sesuai dengan prinsip syariah dan kebijakan amil.

Pengukuran setelah pengakuan awal, Infak/sedekah yang diterima dapat berupa kas atau aset nonkas. Aset nonkas dapat berupa aset lancar atau tidak lancar. Aset tidak lancar yang diterima oleh amil dan diamanahkan untuk dikelola dinilai sebesar nilai wajar saat penerimaannya dan diakui sebagai aset tidak lancer infak/sedekah. Penyusutan dari aset tersebut diperlakukan sebagai pengurang dana infak/sedekah terikat apabilapenggunaan atau pengelolaan aset tersebut sudah ditentukan oleh pemberi. Penurunan nilai aset infak/sedekah tidak lancer diakui sebagai: (a) pengurang dana infak/sedekah, jika terjadi bukan disebabkan oleh kelalaian amil; (b) kerugian dan pengurang dana amil, jika disebabkan oleh kelalaian amil.

Penyaluran Infak/Sedekah, Penyaluran dana infak/sedekah diakui sebagai pengurang dana infak/sedekah sebesar: (a) jumlah yang diserahkan, jika dalam bentuk kas; (b) nilai tercatat aset yang diserahkan, jika dalam bentuk aset nonkas. Penyaluran infak/sedekah kepada amil lain merupakan penyaluran yang mengurangi dana infak/ sedekah sepanjang amil tidak akan menerima kembali aset infak/sedekah yang disalurkan tersebut. Penyaluran infak/sedekah kepada penerima akhir dalam skema dana bergulir dicatat sebagai piutang infak/sedekah bergulir dan tidak mengurangi dana infak/ sedekah.

Adapun beberapa laporan keuangan yang wajib dibuat oleh pengelola masjid. Laporan keuangan yang wajib dibuat oleh pengelola masjid berdasarkan SAK Syariah 109 antaralain.

1) Neraca (laporan posisi keuangan)

2) Laporan perubahan dana 
3) Laporan perubahan asset kelolaan

4) Laporan arus kas

5) Catatan atas laporan keuangan

\section{METODE PELAKSANAAN}

Metode pelaksanaan pengabdian masyarakat ini diselenggarakan dengan metode ceramah, diskusi, dan praktik. Metode tersebut digunakan untuk menyampaikan materi tentang penyusunan laporan keuangan berbasis SAK Syariah 109 khususnya pengelolaan dana infak/sedekah pada SMAN 1 Pakusari Jember. Kegiatan pelatihan untuk penyusunan laporan keuangan berbasis SAK Syariah 109 pada Sekolah Menengah Atas Negeri (SMAN) 1 Pakusari Kabupaten Jember.

\section{Tabel 1 : Jadwal Pelaksanaan Pengabdian Masyarakat}

\begin{tabular}{|l|l|}
\hline WAKTU & KEGIATAN \\
\hline $06.45-07.00$ & Perkenalan Profil SMAN 1 Pakusari Jember \\
\hline $07.00-07.45$ & $\begin{array}{l}\text { Pemaparan materi pendahuluan mengenai SAK } \\
\text { "Pentingnya SAK Bagi Pengelolaan Keuangan" }\end{array}$ \\
\hline $07.45-08.30$ & $\begin{array}{l}\text { Pemaparan materi utama mengenai SAK Syariah } \\
109 \text { “Mengulas Lebih Dalam Mengenai SAK } \\
\text { Syariah 109 khususnya pengelolaan dana } \\
\text { infak/sedekah" }\end{array}$ \\
\hline $08.30-09.40$ & Diskusi \\
\hline $09.40-09.45$ & Penutup \\
\hline
\end{tabular}

\section{HASIL DAN PEMBAHASAN}

Kegiatan pengabdian masyarakat yang dilakukan adalah melalui penyajian materi singkat, diskusi dan praktik penerapan SAK Syariah 109 sebagai media untuk menambah wawasan para siswa/siswi SMAN 1 Pakusari Jember dalam menyusun laporan keuangan berbasis SAK Syariah 109 sehingga diharapkan para siswa/siswi dapat mengelola dana infak/sedekah dalam masjid di lingkungan sekolahnya atau tempat tinggalnya. Pola pelatihan penyusunan laporan keuangan berbasis SAK Syariah 109 lebih dioptimalkan pada pengenalan terhadap apa itu SAK Syariah 109, perlunya siswa/siswi mengenal 
SAK Syariah 109 dan membahas secara mendetail mengenai SAK Syariah 109 sebagai panduan dalam penyusunan laporan keuangan masjid untuk kemudian selanjutnya sesi diskusi mengenai apa saja yang menjadi kendala dalam penyusunan laporan keuangan berbasis SAK Syariah 109.

Faktor pendukung terlaksananya kegiatan pengabdian masyarakat ini antara lain: (1) adanya motivasi dari pihak SMAN 1 Pakusari Jember untuk mengetahui lebih dalam mengenai SAK Syariah 109 ditunjukkan dengan partisipasi aktif dari pihak sekolah sebelum dan saat acara pelatihan penyusunan laporan keuangan berbasis SAK Syariah 109, (2) tingginya antusias dari pihak siswa/siswi SAMAN 1 Pakusari Jember untuk mengikuti seluruh rangkaian kegiatan pelatihan penyusunan laporan keuangan berbasis SAK Syariah 109 yang terlihat pada sesi tanya jawab dan diskusi siswa/siswi SMAN 1 Pakusari Jember menanyakan mengenai tingkat kesulitan yang dihadapi ketika melaksanakan penyusunan laporan keuangan berbasis SAK Syariah 109 dan mengenai perbedaan penyusunan laporan keuangan berdasarkan SAK dibandingkan dengan SAK Syariah 109 serta tambahan ilmu mengenai laporan laba/rugi yang disusun secara SAK dibandingkan secara SAK Syariah 109, dan (3) dukungan dari pihak Lembaga Penelitian dan Pengabdian Masyarakat dan Fakultas Ekonomi Universitas Muhammadiyah Jember sehingga terselenggaranya kegiatan edukatif bagi sekolah untuk menambah wawasan dan ilmu siswa/siswi SMAN 1 Pakusari Jember melalui pelatihan penyusunan laporan keuangan berbasis SAK Syariah 109.

Faktor penghambat dalam kegiatan pengabdian masyarakat ini yakni keterbatasan waktu pelatihan penyusunan laporan keuangan dana infak/sedekah berbasis SAK Syariah 109 yang hanya berdurasi 3 jam untuk pemaparan materi dan diskusi dirasa kurang cukup untuk menyampaikan secara mendetail mengenai keseluruhan yang berkaitan dengan SAK Syariah 109. Pelatihan penyusunan laporan keuangan dana infak/sedekah berbasis SAK Syariah 109 hanya terpantau pada saat dilakukan pemaparan materi dan diskusi. Hal ini tidak menjangkau bagaimana pasca pelatihan dilakukan, sehingga perlu adanya pendampingan atau pembinaan kepada siswa/siswi sebagai pengelola dana masjid di sekolahnya dan di lingkungan tempat tinggalnya untuk membantu siswa/siswi dalam memberikan solusi kendala yang mungkin dihadapi pada saat penyusunan laporan keuangan berbasis SAK Syariah 109. 


\section{KESIMPULAN DAN SARAN}

Salah satu aspek penting bagi penambahan wawasan dan ilmu bagi siswa/siswi adalah mengenai pengelolaan keuangan. Berkenaan dengan pengelolaan keuangan, maka yang dibutuhkan adalah akuntansi. Akuntansi dapat digunakan sebagai instrumen untuk memecahkan kendala dan tantangan dalam hal masalah transparansi untuk pengembangan dana masjid baik di lingkungan sekolahnya atau tempat tinggalnya. Perkembangan kemajuan akuntansi bagi pengeloalaan dana masjid ditandai dengan adanya SAK (Standar Akuntansi Keuangan) untuk masjid yang dinamakan dengan SAK Syariah (Standar Akuntansi Keuangan-berbasis Syariah) produk dari Ikatan Akuntan Indonesia yang resmi diberlakukan efektif 7 Mei 2008.

Perkembangan kemajuan akuntansi pada pengelolaan dana masjid khususnya dana infak/sedekah pada kenyataannya tidak diiringi dengan diterapkannya SAK Syariah 109 pada masjid-masjid di Indonesia. SMAN 1 Pakusari Jember merupakan salah satu sekolah yang berada di Jalan PB Sudirman 120 Kecamatan Pakusari yang memiliki masjid besar digunakan untuk sholat jumat dan ibadah-ibadah besar lainnya. Hal inilah yang mengharuskan SMAN 1 Pakusari Jember untuk mampu mengelola dana masjid dengan transparan guna pengembangan masjid dan bagi kelangsungan kegiatan masjid.

Tujuan dari program pengabdian masyarakat ini adalah untuk meningkatkan pengetahuan mengenai penyusunan laporan keuangan berbasis SAK Syariah 109 pada SAMAN 1 Pakusari Jember. Pengabdian masyarakat ini dilakukan pada SAMAN 1 Pakusari Jember yang berlokasi di Jalan PB Sudirman 120 Kecamatan Pakusari Kabupaten Jember. Kegiatan dilaksanakan dengan metode ceramah mengenai SAK Syariah 109, diskusi antara pemateri dengan siswa/siswi dalam hal ini adalah SMAN 1 Pakusari Jember, dan bagaimana praktik penerapan SAK Syariah 109 pada masjid studi kasus pada masjid Al Ikhlas SMAN 1 Pakusari Jember. Kegiatan ini bertujuan agar siswa/siswi SMAN 1 Pakusari Jember memiliki tambahan ilmu dan wawasan dalam menyusun laporan keuangan berbasis SAK Syariah 109. Kegiatan ini dilaksanakan pada tanggal 31 Oktober 2017 dengan durasi pelatihan selama 3 jam.

Setelah berakhirnya pengabdian masyarakat ini diharapkan adanya dukungan penuh dari berbagai pihak baik dari akademisi, IAI (Ikatan Akuntan Indoensia), dan pemerintah terhadap masjid besar yang belum mengetahui tentang SAK Syariah 109. Dari sisi akademisi dan IAI (Ikatan Akuntan Indonesia), perlu adanya pendampingan dan 
pembinaan bagi pengelola dana masjid yang belum mengetahui mengenai SAK Syariah 109, agar masjid di Indonesia dapat memiliki kekuatan untuk berkembang menjadi masjid yang besar dan transparan dalam pengelolaan keuangan masjid. Dari sisi pemerintah, perlu adanya regulasi yang mengatur mengenai penerapan SAK Syariah di setiap masjid besar sehingga diharapkan masjid mengelola dana yang didapatkannya dengan transparan, sehingga masjid semakin berkembang dan benar-benar berkontribusi positif dalam pembangunan perekonomian nasional serta bisa menarik para donaturdonatur baru untuk menambah modal bagi masjid. Dari sisi masjid, perlu adanya pendampingan pengelola yang memiliki kualifikasi akuntansi syariah sehingga memudahkan dalam penyusunan laporan keuangan berbasis SAK Syariah 109 sehingga dapat berkontribusi dalam peningkatan transparansi pelaporan keuangan masjid.

\section{DAFTAR PUSTAKA}

Andarsari, P.R. 2016. Laporan Keuangan Organisasi Nirlaba (Lembaga Masjid). Jurnal Ekonomi Universitas Kadiri, 1(2), 143-152

Ayub, Muhsin, dan Mardjoned. 1996. Manajemen Masjid. Jakarta: Gema Insani Press

Hanafi, R. 2015. Akuntabilitas dan Pengelolaan Keuangan di Masjid Melalui Pendekatan Fenomenologi (Studi Empiris Pada Masjid Nurusy Syifa' Surakarta). Naskah Publikasi Fakultas Ekonomi dan Bisnis Universitas Muhammadiyah Surakarta. Diunduh dari eprints.ums.ac.id/37119/1/Naskah\%20Publikasi.pdf. Diakses tanggal 18 Agustus 2017 Jam 10.00 WIB

Latif, A. 2014. Akuntabilitas dan Pengelolaan Keuangan di Masjid (Studi Kasus di Masjid Nurul Huda Kecamatan Polanharjo). Naskah Publikasi Fakultas Ekonomi dan Bisnis Universitas Muhammadiyah Surakarta. Diunduh dari eprints.ums.ac.id/32016/9/02.\%20Naskah\%20Publikasi.pdf. Diakses tanggal 18 Agustus 2017 Jam 10.05 WIB

Setiawan, K. 2010. Masjid-Masjid Bersejarah di Jakarta. Jakarta: Penerbit Erlangga

Siskawati, Ferdawati, dan Surya. 2016. Bagaimana Masjid dan Masyarakat Saling Memakmurkan? Pemaknaan Akuntabilitas Masjid. Jurnal Multiparadigma, 7(1): $70-80$

Standar Akuntansi Keuangan Syariah 109

http://iaiglobal.or.id/v03/standar-akuntansi-keuangan/syariah

http://nasional.kompas.com/read/2017/03/04/12144741/raja.salman.terkejut.indonesia.pu nya.800.000.masjid 